\title{
Analysis of Islamic banking financial performance before, during and after global financial crisis
}

\author{
Rifqi Muhammad*, Condro Triharyono \\ Faculty of Economics, Universitas Islam Indonesia, Yogyakarta, Indonesia \\ *Corresponding author: rifqimuhammad@uii.ac.id
}

\author{
Keywords: \\ Financial Performance, CAMEL, \\ Islamic Banking, Global Financial \\ Crisis \\ Article History \\ Received : 28 December 2018 \\ Accepted : 29 January 2019 \\ Published: 2 August 2019 \\ DOI: \\ 10.20885/JEKI.vol5.iss2.art5 \\ JEL: \\ C12, G20, Z12
}

\begin{abstract}
The purpose of this study is to analyze the difference of the financial performance of Islamic banking before, during, and after global financial crisis. This study uses CAMEL ratios which consist of Capital, Asset quality, Management, Earning, and Liquidity ratio. The samples are Islamic banks in South-East Asia and East Asia using secondary data from financial statements of those Islamic banks before (2006-2007), during (2008), and after (2009-2010) global financial crisis. This study examines the hypotheses using Analysis of Variance (ANOVA) as analytical tool. This result shows that there are differences performance on the variables of capital, asset quality, management and earning measured by return of asset (ROA) while earning measured by operating expense ratio (OER) and liquidity do not indicate any differences in financial performance during the period. Thus, banks need to strengthen their liability side during a financial crisis.
\end{abstract}

\section{Introduction}

The global economic crisis that occurred in 2008 had a quite worrying impact on the banking industry worldwide. Global financial crisis occurs due to the problem of market economy in the whole world that cannot be avoided due to bankruptcy or the existence of a chaotic economic situation (Chongvilaivan, 2010). The financial crisis that occurred in the United States also affected other countries which resulted in the bankruptcy of some financial institutions.

Islamic banking was believed to survive during this financial crisis. This is because of the characteristics of Islamic banks that prohibit usury and do not involve in financial derivatives (Al-Qadi, 2012). Islamic banks can maintain their performance although they are also affected by the crisis but their performance is better than conventional banks (Shafique, Faheem, \& Abdullah, 2012). Financial performance then becomes one of the indicators to see the health level of banking industry.

Several previous studies have examined the performance of Islamic banks during the crisis. They argue that it is important to learn why Islamic banking system has less impact from global financial crisis compared to conventional banking system (Al-Qadi, 2012; Shafique et al., 2012). Further, this crisis even increases the popularity of Islamic finance including Islamic banking (Fa-Yusuf, 2016). The stability of performance of Islamic banks needs to be examined to give evidence the strength of Islamic financial institutions.

This study aims to analyze the difference of the financial performance of Islamic banking before, during and after global financial crisis in South-East Asia and East Asia. Goldstein \& Xie (2009) state that that global financial crisis also give impact to the emerging market in Asia marked by decreasing in some key economic variables. However, according to Raz et al., (2012), East Asian successfully minimize the impact of Global Financial Crisis of 2008. Therefore, understanding the financial performance of Islamic banks during that period will provide knowledge of how Islamic banks can maintain their performance. Financial performance of Islamic banks is represented by capital, asset quality, management, earning, and liquidity ratio (CAMEL).

Islamic bank plays an important role in the economy of a country as a financial intermediary with the implementation of Islamic principles (Muhammad, 2019). The dual function of Islamic bank in economic and social roles is one of the advantages of Islamic banks compared to conventional banks. Islamic banks prohibit. One of the characteristics of Islamic banks is to prohibit interest-based loan. According to Othman et al. (2012), the global financial crisis happens because there is selling a debt against a debt and it will not arise in the Islamic banks. Islamic banks implement risk-sharing which means that they share the profits or losses of the clients' business investments. Islamic banks will be more careful when choosing a business to be financed (Hassan, 2008).

However, the global financial crisis is believed to gives impacts to Islamic banks both in negative and positive way. Al-Qadi (2012) mentions the negative impacts from this financial crisis such as reducing the asset 
of Islamic banks because of the lower customer deposits due to lower economic activity, lowering net profit, and increasing operating cost because of restructuring activities. On the other side, global financial crisis also has a positive impact on the Islamic banks (Al-Qadi, 2012): recognition of the role of Islamic banks by international community, increasing number of Islamic banks through converting conventional bank to Islamic one or dual window, increasing deposits of Islamic banks and encouraging the discussion and research about Islamic economy. Elasrag (2010) states that the crisis encourages the evaluation of the capital financial system and try to look for the alternative sources of financing that can be provided by Islamic banks.

Financial performance is one of the indicators of the efficiency in banking industry (Mukhibad, Kiswanto, \& Jayanto, 2017) and used to analyze the health level of financial institution ((Widiarti, Siregar, \& Andati, 2015). CAMEL analysis can be used to measure the effect of global crisis in banking industry (Dincer, et al., 2011). According to Dincer et al. (2011), CAMEL is "a supervisory rating system used for evaluating banks overall financial condition". CAMEL rating is a tool to assess the financial performance and health (Fitch, 1990 cited in Rozzani \& Rahman, 2013). CAMEL covers five aspects of performance that relates to capital adequacy, asset quality, management, earnings and liquidity.

First is Capital Adequacy Ratio. Capital is to back up assets that bring or generate risk. Sarker (2005) states that capital indicates the ability of banks to raise the equity and to absorb the potential loan losses. The strength of capital aspect encourages trust from the community to banks for their financial health. It is important for banking industry to manage the capital structure to be efficient because it will support the strategy of business development, maintain the business continuity and meet the capital adequacy requirement by government (Kumar \& Sayani, 2015). The capital can be divided into core capital such as paid-in capital, premium stock, profits from the previous year, retained earnings and supplementary capital such as capital instrument in the form of shares or others that meet the requirement, amortization based on the remaining period and specific reserves.

Second is Asset Quality. Management of the bank is required to always be able to monitor and analyze the quality of productive assets because it will influence the continuity of the bank's business. The ability of banks in maintaining the quality of asset will appear on the portfolio quality such as the aging schedules and risk portfolio assessment, and productivity of long term asset (Sarker, 2005). The quality of productive assets shows the quality of assets due to the financing risks faced by banks due to lending and investment in bank funds. Each bank's investment in earning assets is assessed for quality by determining the level of collectability. Collectability can be interpreted as the state of repayment of principal, principal installments or profit-sharing of loans by customers and the possibility of the return of funds invested in securities or other investments. The risk of financing received by banks is one of the bank's risks. According to Al-Qadi (2012), assets quality is assessed based on business prospects, financial conditions of debtor cash flows and ability to pay.

Third is Management Capability. According to Sarker (2005), one of aspects of management is strategic planning and budgeting, which refers to the process of institutions to generate financial projections in short and long term. The aspect of management can be represented by Net Profit Margin (NPM). Dincer et al. (2011) argue that the ability of management to produce profit can be used to predict the quality of management.

Fourth is Earning. Earning is an assessment of the company's ability to generate profits on assets owned by the company. Profitability ratio analysis in a bank is a tool to analyze or measure the level of business efficiency and profitability achieved by the bank. Sarker (2005) mentions some measurements of earning such as operational efficiency and return on asset.

Fifth is Liquidity. Banks can use certain ratios to indicate the ability of banks to pay off their obligation or to measure the capacity of banks to close deposits that are not anticipated (Dincer et al., 2011). The ratio of financing to deposit (FDR) will be used in this study because it indicates how strong the ability of banks to repay the withdrawal of funds made by depositors by relying on the financing provided as a source of liquidity.

Several studies have examined the performance of banking sector after the crisis of 2008 using CAMEL method. Dincer et al. (2011) study the performance of Turkish banking sectors after global financial crisis. The banks are divided into three categories, state-owned, private-owned and foreign which then will be measured by using CAMEL during 2002-2009. The study concludes that Turkish banks have learned the impact of crisis on 2001 and got less impact on 2008 than other developed countries.

Rozzani \& Rahman (2013) examines the performance of Islamic and conventional banks in Malaysia from the years 2008-2011. Applying CAMEL method, the study finds that the performance of both banks is similar. Kumar \& Sayani (2015) evaluate the performance of Islamic banks in GCC for the period of 2008-2014 using CAMEL measurement. The performance of Islamic banks in that study gets worse during the period but the impact does not lead to bankruptcy. 


\section{Research Method}

This study uses secondary data taken from financial information in the company's financial statements. Data will be taken on the website of Islamic banking within the period of 2006-2007 (before crisis), 2008 (during crisis), and 2009-2010 (after crisis). The samples of this research are Islamic banks in Southeast Asia and East Asia. The reason for the selection of such samples is because Islamic banking in Southeast Asia and East Asia is more developed and experienced faster recovery post-global-crisis compared to other regions. Variables used in this study are financial performance ratio, which consists of capital adequacy, asset quality, management, earnings and liquidity.

Analysis of Variance test (ANOVA) is used to conduct hypothesis testing. The formula used in this ANOVA analysis is the One-Way ANOVA or often called the design of one factor. This testing tool is used to test whether the performance of Islamic banking before, during and after the global financial crisis has an average that is considered equal or not equal. The ANOVA technique will test the variability of the observations of each group and the variability between mean groups.

There are two steps in using One-way ANOVA, first, Homogeneity Test of Variance measure the basic assumption that all the variables have similar variant. Using Levene test, the variables have similar variant if the probability value is above (more than) 0.05. Second, One-way ANOVA is used to test the hypotheses. The criterion of rejection and acceptance of hypothesis in this study is seen from the significance value of ANOVA Test. The hypotheses are accepted if the probability value is below (less than) 0.05 .

\section{Result and Discussion}

The object of this study is Islamic banking in the Asian region, especially South-East Asia and East Asia. There are 22 Islamic banks from Indonesia, Malaysia, Bahrain, Saudi Arabia, United Arab Emirates, Singapore and Brunei Darussalam with data of financial performance for five years (2006-2010) and therefore, total data are 110 data.

Descriptive analysis aims to view and provide an overview of the characteristics of the data such as mean, median, minimum value, maximum value, and standard deviation. The results of descriptive statistics of each research object are described in Table 1.

Table 1. Result of Descriptive Statistics

\begin{tabular}{lcrrrr}
\hline Variables & $\mathrm{N}$ & Minimum & Maximum & Mean & Std. Deviation \\
\hline CAR & 110 & 8.3 & 49.51 & 19.718 & 8.33079 \\
NPF & 110 & 0.01 & 6.34 & 2.2479 & 1.44637 \\
NPM & 110 & -14.98 & 81.25 & 54.9296 & 17.17207 \\
ROA & 110 & -4.13 & 11.5 & 2.2618 & 2.11013 \\
OER & 110 & 34.75 & 95.31 & 68.3424 & 15.73895 \\
FDR & 110 & 61.25 & 121.81 & 82.1426 & 11.83237 \\
Valid N (listwise) & 110 & & & & \\
\hline
\end{tabular}

Based on Table 1, CAR has a minimum value of 8.30 and a maximum value of 49.51 with an average CAR of 19.72 and a standard deviation of 8.33. The lowest CAR of 8.3 comes from Bank Mega Syariah Indonesia. The CAR has met the minimum requirement because in Indonesia the minimum CAR is $8 \%$. The NPF variable has a minimum value of 0.01 and a maximum value of 6.34 with an average NPF of 2.25 and a standard deviation of 1.45. The largest NPF of $6.34 \%$ comes from Ithmaar Bank in the United Arab Emirates. The mean value of NPF is $2.25 \%$ and shows that the financing problem is quite low on average.

NPM has a minimum value of -14.98 and a maximum value of 81.25 with an average NPM of 54.93 and a standard deviation of 17.17. The largest NPM of $81.25 \%$ in Islamic Finance Bangladesh shows that the management at the bank is good so that they can generate high profit. Variable of ROA has a minimum value of -4.13 and a maximum value of 11.50 with an average ROA of 2.26 and a standard deviation of 2.11. The lowest ROA of $-4.13 \%$ comes from Ithmaar Bank in United Arab Emirates.

The OER variable has a minimum value of 34.75 and a maximum value of 95.31 with an average OER of 68.34 and a standard deviation of 15.74. The lowest OER lowest of 34.75\% comes from Bank Muamalat in Indonesia while the largest OER of $95.31 \%$ come from Khaleeji Bank in Bahrain. This indicates that the use of the cost at the bank is less efficient. The FDR variable has a minimum value of 61.25 and a maximum value of 121.81 with an average FDR of 82.14 and a standard deviation of 11.83 . The highest FDR of $121.81 \%$ in Islamic Finance in Bangladesh indicates that bank liquidity is low because of the high financing compared to the deposit of the bank. 
The CAMEL ratio for each variable can be shown in Table 2.

Table 2. CAMEL Ratio

\begin{tabular}{ccccccc}
\hline Period & CAR & NPF & NPM & ROA & OER & FDR \\
\hline Before crisis & $15.52 \%$ & $4.49 \%$ & $44.33 \%$ & $2.77 \%$ & $89.71 \%$ & $80.18 \%$ \\
During crisis & $14.79 \%$ & $3.84 \%$ & $48.99 \%$ & $2.82 \%$ & $87.74 \%$ & $80.28 \%$ \\
After crisis & $19.25 \%$ & $2.18 \%$ & $56.36 \%$ & $4.21 \%$ & $86.39 \%$ & $81.92 \%$ \\
\hline
\end{tabular}

CAR of Islamic banks before crisis is $15.52 \%$, during the crisis is $14.79 \%$ and after the crisis is $19.25 \%$. There is a decline of CAR in times of crisis, but then after the crisis, CAR shows positive growth reflecting the capability of Islamic banks to improve their capital. This shows that the performance of Islamic banks in terms of capital can recover quickly. The result of this study is in line with the research by Kumar \& Sayani (2015) that state the CAR of Islamic banks in GCC is above 10\% during and after the crisis of 2008.

NPF value has a declining tendency during the period. Before the crisis, NPF is $4.49 \%$ and fall to $3.84 \%$ during the crisis and after the crisis is $2.18 \%$. It indicates that the financing problems of Islamic banks are even lower after the crisis. NPF is the risk of financing received by banks due to the non-repayment of loans given or investments made by the bank. The low NPF after the crisis shows that Islamic banks can manage the risk well. The results of this study contrast with Kumar \& Sayani (2015) who find that NPF of Islamic banks in GCC has increase gradually from 2008 to 2011 but then begin to decline since 2012 until 2014. It shows that after the global economic crisis the performance of Islamic banks has improved and indicates the ability of banks to deal with problematic financing is better.

During the crisis, NPM of Islamic banks obtains a positive growth of $48.99 \%$, which increased from before the crisis, which amounted to $44.33 \%$. In the aftermath of the crisis, NPM of Islamic banks performs a positive growth of $56.36 \%$, increasing from the crisis period of $48.99 \%$. Positive growth shows that the ability of bank management to identify, measure, monitor, and control the risks inherent in all bank activities, guarantees more efficient financial conditions.

The earning aspect is measured by ROA and OER. For ROA, in the pre-crisis period the ROA is $2.77 \%$ during the crisis at $2.82 \%$ and after the crisis at $4.21 \%$. The ROA in Islamic banks experienced positive growth both in the period before, during and after the crisis. Positive growth shows that the greater the level of profit achieved by the bank and the better the position of the bank in terms of asset used. The OER in the pre-crisis period was $89.71 \%$, during the crisis is $87.74 \%$ and after the crisis is $86.39 \%$. Islamic banks experienced positive growth in all period. A positive growth ratio shows that the operating costs incurred by the bank to carry out its main business activities such as interest costs, marketing costs, labor costs and other operating costs are increasingly efficient despite the global economic crisis.

The results of good condition of ROA and OER contrast with a research conducted by Al-Qadi (2012). Al-Qadi (2012) states that the impact of global financial crisis is the low net profit. However, based on the data above the study proves that after the global economic crisis, the performance of Islamic banks shows the good improvement. This may happen because the impact of the crisis on Islamic banks is relatively small and the management also takes policies to prevent the greater impact on the survival of Islamic banks.

FDR in the pre-crisis period was $80.18 \%$ during the crisis at $80.24 \%$ and after the crisis is $81.92 \%$. There is increasing in FDR of Islamic banks in all period. The higher liquidity is indeed maintained by Islamic banks because of two possible reasons, the limited opportunity of interest-free short-term investment and investment in the real economy takes time (Ali, 2012).

Homogeneity of variance is tested to examine the equality of financial performance of Islamic banks before, during and after the global financial crisis. Based on the result of Levene test in Table 4, the significance value of all variables is greater than 0.05 . Therefore, it can be concluded that all variables are similar and qualified for One-Way ANOVA test. The result of ANOVA test is also presented in Table 2.

For Capital Adequacy Ratio (CAR), there is a difference between the performance of Islamic banking before, during and after the global financial crisis of 2008. It can be seen from the significant value which is smaller than alpha value $0.05(0.046<0.05)$, thus $\mathrm{H} 1$ is accepted. The average value of CAR in Table 1 and Table 2 shows that capital adequacy of Islamic banks in Asia is high. According to Rozzani \& Rahman (2013) based on previous studies, CAR value above $11 \%$ performing strong capital for banks. Therefore, although there is a difference in term of CAR during the period, but in general, the strong capital of Islamic banks in Asia is a positive signed that Islamic banks are able to survive during the crisis and expand in the future (Rozzani \& Rahman, 2013). 
Table 3. Result of Homogeneity Test and ANOVA Test

\begin{tabular}{lccc}
\multicolumn{1}{c}{ Hypotheses } & Homogeneity Test & One-Way Anova Test \\
\cline { 2 - 4 } & Sig. Value & Sig. Value & Result \\
\hline $\begin{array}{l}\text { There is a difference in CAR between before, during and after } \\
\text { the global financial crisis of } 2008\end{array}$ & 0.129 & 0.046 & Accepted \\
$\begin{array}{l}\text { There is a difference in NPF between before, during and after the } \\
\text { global financial crisis of 2008 }\end{array}$ & 0.057 & 0.036 & Accepted \\
$\begin{array}{l}\text { There is a difference in NPM between before, during and after } \\
\text { the global financial crisis of } 2008\end{array}$ & 0.77 & 0.04 & Accepted \\
$\begin{array}{l}\text { There is a difference in ROA between before, during and after } \\
\text { the global financial crisis of } 2008\end{array}$ & 0.608 & 0.048 & Accepted \\
$\begin{array}{l}\text { There is a difference in OER between before, during and after the } \\
\text { global financial crisis of 2008 }\end{array}$ & 0.675 & 0.997 & Rejected \\
$\begin{array}{l}\text { There is a difference in FDR between before, during and after the } \\
\text { global financial crisis of } 2008\end{array}$ & 0.595 & 0.825 & Rejected \\
\hline
\end{tabular}

The significant value of $\mathrm{H} 2$ shows 0.036 that lower than alpha value $(0.036<0.05)$. It means that there is a difference between the asset quality of Islamic banking measured by Non-Performing Financing (NPF) before, during and after the global financial crisis of 2008 and thus, $\mathrm{H} 2$ is accepted. Based on Table 3, there is decline of NPF after the crisis compared to before and after crisis. This result proves that Islamic banks can manage the NPF at a low level regardless of the bad economic condition. This study supports the previous study conducted by Jaffar \& Manarvi (2011) who state that Islamic banks in Pakistan can maintain Capital Adequacy and Asset Quality well.

NPM as a proxy for management has significant value 0.040 which is smaller than alpha value 0.05 $(0.040<0.05)$. The result shows that there is a difference between the performance of Islamic banking measured by Net Profit Margin (NPM) before, during and after the global financial crisis of 2008. Thus, H3 is accepted. Al-Qadi (2012) finds that management and internal parties in companies have important role to protect the company during financial crisis. Their action may influence the performance of organization before, during and after the crisis, thus performance degradation can be prevented.

Hypothesis 4 measures the earning of Islamic banks using ROA. The significant value of 0.048 is lower than alpha value $0.05(0.048<0.05)$ meaning that there is a difference between the ROA of Islamic banks before, during and after the global financial crisis in Asia region. Therefore, H4 is accepted. The data in Table 3 shows that there is increasing in ROA even during and after crisis. According to Goldstein \& Xie (2009), the impact of financial crisis in Asia can be managed because the company in these countries enter the crisis in the good condition indicating by low leverage ratio and high profitability. Therefore, the profitability of Islamic banks can be maintained well.

The statistical test of OER shows the significant value of 0.997 that is greater than alpha value 0.05 (0.997> 0.05). It indicates that there is no difference between the earning of Islamic banking measured by Operating Expense Ratio (OER) before, during and after the global financial crisis. Thus, H5 is rejected. Although the value of OER can be improved during and after the crisis (see Table 3), but this result does not support the argument of Al-Qadi (2012) that global financial crisis will increase the operating cost. This can be caused by policies taken by Islamic banks to deal with the crisis such as downsizing the organization structure and limiting expansion. These actions may give impact on the lower earning and also lower operational costs, which make no difference on OER throughout that period.

From Table 3, the significant value of FDR is 0.825 that higher than alpha value of $0.005(0.825>$ 0.05). The liquidity of Islamic banks in Asia has no difference before, during and after the global financial crisis of 2008 and H6 is rejected. Based on Table 3, Islamic banks have high liquidity of more than $80 \%$. According to Ali (2012), The high liquidity of Islamic banks is needed as risk management purpose because of the limited access to market liquidity. Furthermore, the characteristics of profit and loss sharing in their transaction that sharing the risk of failure equally between Islamic banks and client need the liquidity position to be quite high (Kumar \& Sayani, 2015). Therefore, it is important for Islamic banks to maintain their liquidity. 


\section{Conclusion}

The study measures whether there is a difference in financial performance of Islamic banks in Asia region before, during and after the global financial crisis of 2008. Four aspects of CAMEL namely Capital, Assets, Management and Earning measured by ROA have difference in that period, while liquidity and earning measured using OER do not differ before, during and after the global financial crisis.

The results indicate that most of the ratio shows positive improvement after the global crisis than before the crisis. It means that in several aspects in CAMEL (Capital, Assets, Management and Earning measured by ROA) can be maintained in good performance. The global financial crisis has an impact on Islamic banks both positively and negatively. However, the characteristics of Islamic bank that apply sharia principles become strongholds of deterioration due to the crisis. It should encourage Islamic banks to better market their products and services to the society.

The study is expected to contribute in the literature about the using of CAMEL in evaluating the performance of Islamic banks before, during and after the global financial crisis of 2008. The results can be used to enhance the confidence of Islamic banks and their customers in doing transaction with Islamic banks. The future studies can examine the impact of the crisis on the performance of other Islamic financial institutions such as Islamic insurance or compare the impact of crisis between Islamic and conventional institutions. However, the adoption of CAMEL method in measuring the performance of an institution should be accompanied by looking at the existing regulation in each country. It is to ensure conformity between the methods of performance measurement and applicable rules.

\section{References}

Al-Qadi, N. S. (2012). The Impact of Global Financial Crises on Islamic Banks. International Journal of Financial Economics and Econometrics, 4(2), 1-18.

Ali, S. S. (2012). Islamic Banking in the MENA Region. IRTI Working Paper Series, 1433-1. Retrieved May 12 , 2019, from http://www.irti.org/English/Research/ Documents/WP/WP-1433-01.pdf

Chongvilaivan, A. (2010). Global Financial Crisis and Growth Prospects in Asia-Pacific: A Sectoral Analysis. In The 26th Conference of the American Committee for Asian Economic Studies, Kyoto, Japan, 5-6 March.

Dincer, H., Gencer, G., Orhan, N., \& Sahinbas, K. (2011). A Performance Evaluation of the Turkish Banking Sector after the Global Crisis via CAMELS Ratios. Procedia - Social and Behavioral Sciences, 24, 1530-1545.

Elasrag, H. (2010). Global Financial Crisis and Islamic Finance. Retrieved May 15, 2019, from https://ssrn.com/abstract=1591563

Fa-yusuf, H. (2016). Avoiding Financial Crisis: In Support of Islamic Financial Institutions. ISRA International Journal of Islamic Finance, 8(1), 173-181.

Goldstein, M., \& Xie, D. (2009). The Impact of the Financial Crisis on Emerging Asia. In Asia and the Global Financial Crisis (pp. 1-64). Federal Reserve Bank of San Fransisco.

Hassan, A. (2008). The Global Financial Crisis and Islamic Banking. Retrieved May 12, 2019, from http://www.islamic-foundation.org.uk/IslamicEconomicPDF/Hassan-financialcrisis.if.pdf.

Jaffar, M., \& Manarvi, I. (2011). Performance Comparison of Islamic and Conventional Banks in Pakistan. Global Journal of Management and Business Research, 11(1), 60-66.

Kumar, V., \& Sayani, H. (2015). Application of CAMEL Model on the GCC Islamic Banks: 2008-2014. Journal of Islamic Banking and Finance, 3(2), 1-14.

Muhammad, R. (2019). Akuntansi Keuangan Syariah: Konsep dan Implementasi PSAK Syariah, Edisi 3. P3EI Press Yogyakarta.

Mukhibad, H., Kiswanto, \& Jayanto, P. Y. (2017). An analysis on financial and social performance of Islamic banks in Indonesia. Int. J. Monetary Economics and Finance, 10(3/4), 295-308.

Othman, R., Aris, N. A., Azli, R. M., \& Arshad, R. (2012). Islamic Banking: The Firewall Against The Global Financial Crisis. The Journal of Applied Business Research, 28(1), 9-14.

Raz, A. F., Indra, T. P. K., Artikasih, D. K., \& Citra, S. (2012). Krisis Keuangan Global dan Pertumbuhan 
Ekonomi: Analisa dari Perekonomian Asia Timur. Buletin Ekonomi Moneter Dan Perbankan, 15(2), 37-56.

Rozzani, N., \& Rahman, R. A. (2013). Camels and Performance Evaluation of Banks in Malaysia: Conventional Versus Islamic. Journal of Islamic Finance and Business Research, 2(1), 36-45.

Sarker, A. A. (2005). CAMELS Rating System in the Context of Islamic Banking: A Proposed "S" for Shariah Framework. Journal of Islamic Economics and Finance, 1(1), 78-84.

Shafique, A., Faheem, M. A., \& Abdullah, I. (2012). Impact of Global Financial Crises on the Islamic. Arabian Journal of Business and Management Review (OMAN Chapter), 1(9), 124-134.

Widiarti, A. W., Siregar, H., \& Andati, T. (2015). The Determinants of Bank's Efficiency In Indonesia. Bulletin of Monetary, Economics and Banking, 18(2), 121-146. 